\title{
Modernising the European Social Paradigm: Social Investments and Social Entrepreneurs
}

\author{
JANE JENSON \\ Department of Political Science, Université de Montréal, CP 6128, Succursale Centre-Ville, \\ Montréal, QC, H4L 2H8 Canada \\ email: jane.jenson@umontreal.ca
}

\begin{abstract}
Policy perspectives of the European Union as well as those of member states currently link the concepts of social investment and social entrepreneurship in order to advocate both where and how to intervene. The argument of this article is that the explicit linking of these two notions, by policy-makers at several different levels and scales of authority, constitutes an emerging policy paradigm. The article identifies three characteristics of any paradigm, including that a policy paradigm must provide a perspective on the maintenance of the well-being of both society and individuals. Despite variation across countries and levels of authority (a characteristic of any paradigm) policy communities proffer the quasi-concepts of social investment and social entrepreneurship in combination as the appropriate ways to govern financing and the delivery of social investments. Therefore, social enterprises are targeted to receive public financing in order to deliver social investments in activation (training, employability, job support and wage supplements) as well as childcare. Reliance on this assemblage is documented across scales from the local through the national, transnational and international.
\end{abstract}

\section{Introduction}

Analysts of social policy often pay more attention to the content of social policy than to its governance. Now, however, it is important to assess both. There is little dispute that over the last two decades the promotion of social investment has risen in prominence. Increasingly, it is also evident that another policy concept is being added to the mix, one traditionally less associated with social policy and frequently below the radar of social policy analysts. This concept is social entrepreneurship, considered in many policy communities as the source of appropriate innovations in social policy delivery and financing. Policy perspectives of the European Union as well as those of member states currently tend to link the concepts of social investment and social entrepreneurship.

The argument of this article is that the explicit linking of these two notions by policy-makers at several scales of authority constitutes an emerging policy 
paradigm. Any new social policy paradigm must provide a perspective on the maintenance of the well-being of both society and individuals. Both concepts, in combination, are proposed as the route to this dual benefit. The two notions are promoted by various policy communities who assert that social innovations, especially social entrepreneurship, social enterprise and quasi-markets, can provide ways to promote social investments while avoiding the limits of both 'big business' driven by profit-seeking and 'big government' driven by the practices and controls of Weberian-style public administrations. Thus, as the claims go, effective social investments will be more likely to be correctly identified and properly implemented if they are left to market-making and market-modelled social entrepreneurs. This strategy is described as providing a set of policies and instruments that can address the challenges of fostering social inclusion and social cohesion, that is societal well-being, as well as addressing the needs of individuals and families.

In a recent manifesto for self-promotion, we find a good example of the ambitions of social entrepreneurs with respect to several dimensions of social solidarity: ${ }^{1}$

Europe's economic and social model needs to reinvent itself. We need growth that is fairer, greener and anchored in local communities. A model that values social cohesion as a genuine source of collective wealth. Social enterprises are recognised as a vehicle for social and economic cohesion across Europe as they help build a pluralistic and resilient social market economy. Building on the strengths of a long social economy tradition, social entrepreneurs are also drivers of change, creating innovative solutions to the big challenges that face us today. Acting in the general interest, they create jobs, provide innovative products and services, and promote a more sustainable economy. They are based on values of solidarity and empowerment; they create opportunities and hope for the future.

Social policy-makers share social entrepreneurs' enthusiasm; they too offer the instruments, institutions and philosophy of social enterprise and the social economy as the way to make social investments, and as the best route to achieving social inclusion and cohesion. As Social Europe (2013: 19) asserts with respect to the social economy, for example: 'The complementary role played by these initiatives with respect to public and for-profit actors has been over the past few decades the most far reaching innovation for reconciling equity and efficiency, moving towards a new European economic and social model.' The expressed enthusiasm of both social entrepreneurs and policy communities for remaking the social model with new forms of governance confirms the need to devote attention to the ways in which ideas and practices about social investment and social enterprise are moving together. ${ }^{2}$

The contention of this article is that this market-making for social investments completes a new social policy paradigm, promoted at EU-level as well as within national states. In other words, rather than being analysed as separate initiatives, the discourses and instruments of social investment and of 
social entrepreneurship must be understood as an ensemble generating a social policy paradigm.

\section{A conceptual framework for a paradigm}

The concept of paradigm is often deployed in discussions of political change. Given its appeal as a heuristic, the concept is invoked more than it is parsed. For example, Cantillon and Van Lancker (2013) simply announce social investment is the 'dominant paradigm' and then go on to critique it. Similarly van Kersbergen and Hemerijck (2012) analyse the 'social investment paradigm' but again without parsing the meaning of the concept of paradigm; all effort goes into describing social investment. Heuristic use of the concept may be appropriate if the analytic goal is simply description. More conceptual work is helpful, nonetheless.

The literature suggests three characteristics of paradigms. The classic treatment of a policy paradigm by Peter Hall is that it is an interpretative framework' or a 'coherent system of ideas' (1993: 279) that gives meaning to policy objectives, the choice of instruments and even their settings. ${ }^{3}$ Armed with a 'prevailing set of policy ideas' (Hall, 1993: 383), policy-makers in Europe and North America after 1945 could all invoke Keynes, while implementing different instruments and settings and even having diverse objectives, all of which were justified in terms of the common principles of the Keynesian paradigm. Jane Jenson (1989: 74) defined a 'societal paradigm' as 'a set of interconnected premises which make sense of or give meaning to many social relations,' and then analysed the ways in which a general Fordist perspective was adapted to the specific institutional and political conditions of post-1945 Canada. For his part, William Coleman (1998) used the concept of a 'developmental paradigm,' widely shared among post-1945 agricultural policy-makers, to examine variation in three cases (France, Germany and the USA). He sought to pinpoint the consequences of policy-makers' particular stance within the general interpretative framework. Formulated this way, Coleman's use of the concept of paradigm allowed space for variation within a common frame, as did Hall's and Jenson's. Following these authors, we consider that for a paradigm to exist it is never necessary that there be complete consensus about how it will be translated into practice. Variation is expected. This is the first important characteristic of the concept of paradigm that underpins the analysis here.

We can attribute this variation within consensus to the fact that paradigms are composed of quasi-concepts, which is their second characteristic. Bernard (1999: 48) identified a quasi-concept as a hybrid, making use of empirical analysis and thereby benefiting from 'the legitimising aura of the scientific method,' but simultaneously characterised by an indeterminate quality that makes it adaptable to a variety of situations and flexible enough to follow the twists and turns of policy that everyday politics sometimes makes necessary (also European 
Commission, 2013c). The power of quasi-concepts is their ambiguity, a polysemy that allows them to be used by policy-makers both to analyse the situation and to forge a consensus (Jenson, 2010: 71). As such, they contribute to the political consensus needed for policy action and to assemble supporters, both nationally and globally (Kennett and Lendvai, 2014). Both social investment and social entrepreneurship are quasi-concepts whose definitions vary among users and uses.

A third feature of the concept of policy paradigm is that it organises relations across sectors. Here the theoretical approach often substitutes the concept référentiel for that of paradigm. ${ }^{4}$ Coleman (1998: 634), for example, draws on the work of Bruno Jobert and Pierre Muller to insist on interconnections across sectors, in his case the ideas about state-society relations at the broadest level and those shaping agricultural policy. This is in other words, a vision of nested sets of ideas and practices that are ordered hierarchically from the most general to the more specific. 'After-neoliberalism' is a broad référentiel ordering ideas about social policy, such as the social investment perspective (Dufour et al., 2008; Morel et al., 2012: 46). Included in this nested set are policy ideas about the causal connections between production and markets and social policy interventions (Deeming and Smyth, 2015). Such ideas construct a discourse about the conditions for societal well-being (economic growth; social cohesion; etc.) alongside one about individual behaviours (parents' investment in children's social capital, for example).

These three characteristics shape the major theoretical contention of this article: in order for a new social policy paradigm to take shape, it must provide a general blueprint for promoting well-being, both of the society and of individuals. The first characteristic of a paradigm implies that the blueprint will be anchored by common principles shared across jurisdictions that take on specific expression in individual cases. The second is that it will be composed of quasi-concepts that provide the policy-analytic space for such variation as well as for building support within institutions and among the population. The third characteristic implies that ideas will be nested across levels and sectors, a situation that can be expressed as the need for a politically convincing narrative about the relationship between all four segments of the welfare diamond: the market, the state, the community and the family; and this with respect to societal needs as well as individual well-being.

This diamond is a metaphor for the mixed sources of well-being. ${ }^{5}$ Each of its four corners is a potential source of well-being and provides instruments for risk sharing. Political discourse about individual (and family) behaviours as well as societal development and well-being has, of course, changed significantly over time. After 1945 the welfare regime (no matter its specific type) was considered to be a driver of economic growth and well-being. ${ }^{6}$ Individuals and families' labour market behaviour was to be supplemented, however, by social services, themselves 
sources of job creation, and by income transfers such as family allowances, pensions and unemployment insurance that would infuse the economy with needed cash in times of downturn, in order to ensure the well-being of the economy. This premise was, of course, rejected by neoliberals starting in the 1980 . They described the welfare state as 'the problem' and rejected many notions of solidarity. Neoliberal theorists concentrated on exposing a supposed tradeoff between economic growth and state spending on social policy, describing societal well-being as derivative of 'market fundamentalism'. In turn, individual well-being was designated the 'responsibility' of the individual and the family (for a summary see, for example, Evans and Sewell, 2013: 36). To the extent that neoliberals paid attention to social policy, the goal was to de-legitimate any resort to claims for social rights and to promote a concomitant 'individualization of risk, reward and responsibility' (Jenson and Levi, 2013: 82; Evers and Guillemard, 2012). Thus, effective market behaviour was the key to both individual and societal wellbeing, with risks being faced by families and, as a last resort, the community. The space of the state in the welfare diamond was supposed to shrink dramatically.

By the mid-1990s, however, fears of the consequences of uncontrolled neoliberal market fundamentalism led even its most enthusiastic supporters to be worried about society and its cohesion. ${ }^{7}$ A new frame was adopted within national, transnational and international institutions, based on the analysis of a shifting structure of social risks. As documented below, policy-makers, albeit with differential levels of enthusiasm, embraced social investments (in human capital and to promote labour market activity) and social innovations (in the form of social entrepreneurship and enterprises) to respond to these risks. ${ }^{8}$ Social investment and social entrepreneurship are the key quasi-concepts that underpin this 'modernised' narrative of social policy by promising to foster social cohesion and generate social inclusion - both being good for society-and support individuals with services and transfers so their well-being can be improved.

\section{Redesigning policies: using social enterprises to make social investments}

This modernised narrative often depends on promoting forms of governance designed to include numerous actors, with the state financing services in whole or in part but not necessarily delivering them. Rather than privileging state provision, as in the Keynesian welfare state, or commercial and private provision as neoliberalism prescribed, the tendency is to turn to marketbased social entrepreneurs. The quasi-concept social entrepreneurship implies and opens space for a variety of relationships to the public sector. These relationships are used to govern public-sector interventions derived from the second quasi-concept, that of social investment, and seek to address the new social risks, including: 'reconciling work and family life, lone parenthood, long-term 
unemployment, being among the working poor, or having insufficient social security coverage' (Bonoli, 2005: 431). The application of the two varies across jurisdictions, of course, but the common principles of this paradigm can be identified and are deployed by numerous actors at all scales of intervention.

\section{Making social investment for individuals and societies}

Despite variation, there is consensus that the social investment perspective stands on two principles. First, the perspective is based on a diagnosis of the needs of the knowledge-based economy in order to sustain social protection, especially pensions, as well as to ensure social inclusion. The treatments to be applied are reform of social protection, with policies and programmes that better prepare children for the future, including the breaking of the intergenerational transmission of disadvantage. Concretely this perspective primarily translates into greater attention to early childhood education and care (Mahon, 2010; European Commission, 2013a) and to education as an investment in human capital. ${ }^{9}$ In this way the hope initially expressed via a book dedication has become a policy principle, most recently expressed in the EU's Social Investment Package: 'Focusing on children is vital for a sustainable, efficient and competitive knowledge economy and an intergenerational fair society. The adequacy of future pensions depends on the human capital of those who are today children' (European Commission, 2013b: 13 ). ${ }^{10}$

Second, in large part because of the importance of parental employment to breaking the intergenerational cycle of disadvantage, the second principle of the social investment perspective involves raising employment levels. Indeed, early childhood education and care usually has a double mission - of preparing the future labour force and promoting women's employment (Social Europe, 2013: 11 and passim; Morel et al., 2012: 154-55). This principle involves a reformulation of the standard neoliberal argument for activation, which assigned to individuals the responsibility for their own well-being. From a social investment perspective, children do better when parents are employed, and therefore public support must be available to allow them to enter and stay in the labour market (Jenson and Saint-Martin, 2003: 93). This was the mantra of New Labour after 1997, whose main idea about how to end child poverty was to combat 'worklessness' by moving parents into employment, with various employment supports as well as wage supplements to 'make work pay' (Deeming and Smyth, 2015:3). It continues through the EU's attention to avoiding 'inactivity traps' into which parents may fall as well as to increasing labour force participation of lone parents (European Commission, 2013b: 10-11).

Since the mid-1990s, the social investment perspective has been advanced as a route towards societal well-being via greater social cohesion and social inclusion. ${ }^{11}$ In 1996, for example, a high-level OECD conference seeking 'a new social policy agenda' called for a new framework, labelled a 'social investment approach' 
based on the goal of maximising social cohesion (quoted in detail and with other examples from these years in Jenson, 2012: 21-22). The European Commission (2013b) framed the Social Investment Package as a tool for achieving social inclusion. According to the argument, social cohesion would also be improved.

Where do social innovation, social entrepreneurship and social enterprises fit in this ensemble? Why does the European Commission (2013b: 11) assert that 'social enterprises together with the third sector can complement public sector efforts, and be pioneers in developing new services and markets for the citizens and public administrations...'? Among other reasons, from the social investment perspective lone mothers and underemployed mothers are a prime target for integration into the labour force and therefore as clients of 'work integration social enterprises' or WISE. ${ }^{12}$ In addition, childcare, intended to ensure investment in human capital, has become a major domain for social enterprises (Nyssens, 2006: 18; 263 and passim; Social Europe, 2013: 15). Public funding now goes to non-public and non-profit actors to develop services needed to implement the social investment perspective in areas that would have been provided by the public sector in the Keynesian era or commercially where neoliberals held sway. This shift involves deployment of a discourse that relies on the quasi-concept of social entrepreneurship.

\section{Social enterprises for service delivery}

Innovation in social service delivery according to principles of market-like behaviour, social entrepreneurship and quasi-markets, involves addressing new social risks by expanding markets as well as shifting relationships among families, the community and the state. ${ }^{13}$ The relationship to the state sector varies, with different jurisdictions choosing from a buffet of modalities. A recent EU report provides a partial list of four ways in which public money is being used across Europe to support, as well as encourage, social enterprises' activity in the domain of social services: (i) allocating a public subsidy to private providers of social services, with few restrictions or conditions on how it is spent; (ii) providing incentives to provide a service, by offering public funds in exchange for meeting objectives set by the state; (iii) contracting-out and paying for a specific service according to parameters set by the state; (iv) funding purchase of the services of social enterprises by providing vouchers to individuals (Social Europe, 2013: 83).

One source of market-based discourse and the focus on market-making comes from promotion of the social economy. ${ }^{14}$ A recent study commissioned by the European Commission (Social Europe, 2013: 36) provides an overview and tally while chronicling the involvement in service delivery of the social economy and social enterprises more generally: 
or the UK show a more diverse picture, though with a common, significant presence of social enterprises providing community, social and related services. In other countries (such as Italy for example) the two main fields of activity are work integration and welfare service provision.

Studies of these social enterprises also find that, while states and other public authorities continue to finance interventions to address social risks, they are much less willing to design policy that involves them directly in delivery. Instead they turn to social enterprises operating in the market sector of the welfare diamond using a range of instruments to form the relationship. Some of these are vaunted as more innovative than others, by allowing social enterprises to innovate by deftly responding to current and changing needs better than either the state or the private sector. As Social Europe enthusiastically puts it (2013: 87): 'Quite often, supporting social enterprise creation and development has allowed public policies to meet employment and other social and economic challenges in a more efficient and effective way than relying on the public or private sectors alone, thereby achieving greater value for taxpayer's money.' The objectives are both societal, usually social inclusion and cohesion, as well as shifting individual behaviour, usually employment or good practices in child-rearing.

Labour markets are one key domain in which market-building by social enterprises with the support of public funds has occurred, thereby engaging directly with the social investment perspective. The social and labour market policy analysis underpinning interventions rests on the recognition that it is no longer possible to count on traditional firms to provide 'full employment.' In the distant past (after 1945 that is) the labour market appeared to operate more smoothly, creating an adequate supply of (male) jobs and absorbing most jobseekers. Public policy makers could confine their market-shaping role to regulations about hiring and working conditions as well as general education and unemployment insurance for what were expected to be shortterm dislocations. The market also provided an expanding array of goods and services, appearing to meet all needs. Now, however, and this for several decades, both growing needs for many kinds of new services (especially for social care and environmental protection) unmet by markets, as well as for job creation and labour-market integration, have become a major preoccupation within social policy communities.

That the seemingly smooth operation of the labour market and of service provision can no longer be assumed, has meant that policy-makers in numerous regimes have turned to fostering and supporting market actors such as social enterprises that they hope will simultaneously achieve two modifications. First, to help to train and prepare workers facing one or more of the new social risks to enter paid employment. Second, to increase the labour market's need for workers by expanding and better organising markets for new goods and services which traditional firms do not adequately offer. The second modification frequently 
evokes mentions of needs for social care (for the elderly, disabled and children) as well as training, although many types of services might be provided in these markets.

Many have pinned their hopes on social enterprises that can act as job creators as well as 'work integration enterprises' (Evers et al., 2014: 15-16). Initiatives, often coming from the community as well as the market sector of the welfare diamond, may seek to shape either - and sometimes both - the supply and demand structures of labour markets, and to do this with the support of public authorities. On the supply side, and usually in the name of social inclusion, they work to enable integration into the labour market of young people, women, lone mothers, new immigrants and the long-term unemployed - the groups most touched by the new social risks, in other words (numerous national examples are in Nyssens, 2006). These enterprises' integration efforts are a policy instrument for the achievement of the 'activation' commitment of European social and economic policy which is also a pillar of the social investment perspective (Evers and Guillemard, 2012: chapter 7) and are meant to foster social cohesion as well as improve individuals' income. On the demand side, reliance on social enterprises creates jobs for trainers, counsellors, and so on, sometimes replacing public sector employment for similar jobs.

The popularity of the quasi-concept among policy communities means that social enterprises, and the social economy more generally, are often tasked with filling gaps in services that do not attract investment by private-sector firms, but which the state will not take up. To do so they need employees, thereby creating jobs. In this context, reliance on social enterprises is proposed to address existing gaps in the market corner of the welfare diamond, and particularly its failure adequately to provide products and services for social care for elders, children, or other vulnerable persons. Environmental services are also a favourite focus.

Some examples illustrate key actors' perspective on the contribution of such social entrepreneurship to governance of the social investment perspective. The OECD has long been concerned with promoting higher employment rates but has also increasingly become cognisant of market imperfections (Mahon and McBride, 2008). It has been actively constructing an analysis of how to address social challenges by relying on social innovations and entrepreneurship. The OECD's Oslo Manual now recognises a social dimension to innovation to address 'global and social challenges', and social enterprises are the chosen instrument to respond to such challenges (OECD, 2010a: 182; 2010b: chapter 5). This deployment of the quasi-concept of social entrepreneurship suggests, in other words, alternative ways of meeting the challenges of societal and individual well-being.

Of course the OECD is not alone in seeing social entrepreneurs and their market behaviour as a pillar of the social investment perspective, contributing to individual and societal well-being. The European Union has also been moving 
in this direction, and even more enthusiastically so since the 2008 economic crisis. The EU launched its Social Business Initiative (SBI) in 2011. Initially the potential for 'social business' was broadly cast to include all types of firms from multinationals to social enterprises. ${ }^{15}$ Quickly, however, the SBI narrowed down to focus only on social entrepreneurs and their businesses, which were valued because 'social enterprises seek to serve the community's interest (social, societal, environmental objectives) rather than profit maximisation. They often have an innovative nature, through the goods or services they offer, and through the organisation or production methods they resort to ... . ${ }^{16}$ The promise of social innovations and social enterprise was incorporated into the European Union's Europe 2020 strategy, ${ }^{17}$ and a series of high-profile interventions have signalled that the Union shares the views of those who see a greater role for social enterprises in achieving its targets for social inclusion and poverty reduction, via their potential for job creation and innovative service provision. The EU contributes to encouraging and supporting such market actors via actions such as the 2014 conference on Empowering social entrepreneurs for innovation, inclusive growth and jobs. At that event workshops focused on the 'potential of social enterprises for job creation and green economy' as well as on the ways that the EU could use its structural funds to support and foster social enterprises. ${ }^{18}$ Leverage for jobs, social inclusion and green initiatives were all identified as necessary because inadequately addressed by traditional firms.

It is not only international or supranational organisations that promote the quasi-concept of social enterprise to implement the social investment perspective. The major cross-national study of social cohesion and innovation reported in Evers et al. (2014) documented, as already noted, that 'work integration enterprises' were the most common innovation in local welfare systems. These kinds of businesses cross boundaries within the welfare diamond between market and community, often being difficult to distinguish from the kinds of autonomous community groups and associations that engage in social development projects, frequently at the local level (Moulaert et al., 2010; Nicholls and Murdock, 2012).

Social policy communities' enthusiasm for the market participation of social entrepreneurs and the social economy in the governance of social services has had to go beyond cheer-leading and publicising best practices, of course. New practices of governance have been instituted as public funds flow to services that are no longer provided as public services in the classic meaning of the term, that is provided by public employees at no cost (or little cost) to users. 'Many if not most of the SIs [social innovations] we dealt with rely on a multiplicity of resources and their combination; the mix may vary and state financing may often be the most important component, but in most cases there is a degree of (financial) co-responsibility of other organizations from the civil society or the business sector' (Evers et al., 2014: 22). In other words, local, regional, national or European public authorities were actively using their available public funds to 
foster local innovations in labour-market services. They were engaged in marketmaking and in reconfiguring boundaries between public and other forms of services.

The second pillar of the social investment perspective has also turned to social enterprises and market-making in order to promote societal as well as individual-level well-being. Childcare services have expanded significantly across Europe, with stable or greater public financing of childcare services between 1998 and 2009 in every European country except Luxembourg (OECD, 2014: PF3.1). Nonetheless, while public spending increased or at least remained stable, many jurisdictions reduced or limited their own direct service provision and provided incentives to social enterprises to organise the service.

For example, Sweden is a country often identified as an early adopter of the social investment perspective (Deeming and Smyth, 2015: 298). In the 1980s it began to innovate in forms of service provision in the name of 'choice' (Blomqvist, 2004). ${ }^{19}$ With respect to services for children, this involved reducing the dominant position of the municipal childcare centre, which had been the primary form of service provision from the 1960 s on. Private and for-profit pre-schools (as childcare centres are called in Sweden) were permitted to receive public funding similar to that of municipal centres beginning in 1992. The form of private provision that had inspired the original break with exclusively public provision was a type of social enterprise, the parental cooperative. ${ }^{20}$ Reliance on publicly funded pre-schools provided by institutions other than the municipality (but funded by it) has expanded significantly and the market in childcare has grown. ${ }^{21}$ By 2010-11, across Sweden the number of children attending a non-public preschool was 19 per cent. Nonetheless, the parental cooperative and other non-profit forms remained the most usual alternative, at 11 per cent of the total (Brennan et al., 2012: 383). However, the share of provision by these alternative pre-schools has varied widely, ranging from 1 per cent to 47 per cent across all municipalities. The higher share is concentrated in urban areas and better-off neighbourhoods (Blomqvist, 2004: 150).

The United Kingdom after 1997 was a convert to the social investment perspective and innovation in public investments often relied on drawing in voluntary organisations (Milbourne and Cushman, 2015: 464). The role of social enterprises in the childcare domain has differed from that of Sweden, however, because the UK has historically been one of the countries that relied most on private (both for-profit and non-profit) forms of financing services as well as of providing them (OECD, 2005: 93; Brennan et al., 2012: 383, for England). The kinds of actors in the market multiplied as the social investment perspective took hold, however, and social enterprises of various sorts captured a greater market share from private-sector providers (OECD, 2005: 131).

The National Childcare Strategy implemented in 1998 altered the playing field in a major way by encouraging reliance on social entrepreneurs in 
cooperation with local authorities. 'In England, each local authority is now expected to develop, plan and coordinate childcare and early years services including nurseries, children's centres, day-care services, playschools and outof-school-hours care' (OECD, 2005: 99). The municipal childcare centre is not a common form of service, however; only 12 per cent of childcare in 2010-11 was provided by a public agency (Brennan et al., 2012: 383). 'Working with their partners through Children's Trusts (partnerships including local community representatives, Jobcentre Plus, schools, health agencies, NGOs and commercial private childcare providers) local authorities are responsible for local childcare facilities to serve local needs' (OECD, 2005: 99). In England in 2010-11, 17 per cent of childcare services were delivered by a non-profit provider (Brennan et al., 2012: 383).

Several incentives provide support for the development of the childcare market via social enterprises such as worker or parent cooperatives, service cooperatives, community nurseries and so on (SEL, 2002), as well as for forprofit provision. These incentives range from direct subsidies and seed funding to tax reductions to parents so they can use the service (OECD, 2005: 23). The boundaries between social enterprises that are for-profit and those that are nonprofit are blurred by the legal status many rely on, that of the Community Interest Company (Social Europe, 2013: 34). Research reports 'many small businesses with a well-developed social ethic and purpose' (Capacity, 2008: 4) and thus some of the 72 per cent of childcare reported as for-profit provision (Brennan et al., 2012: 383) also depends on social entrepreneurs.

All such strategies are responses to the recognition that in many situations traditional market practices and institutions have proven themselves inadequate to the task of supporting social investment policy strategies and public financing has become one of the key sources for a whole set of social enterprises working within the market corner of the welfare diamond.

\section{Conclusion}

The analytic attention given to the social investment perspective has exploded, as have policy evocations of the need to transform policy interventions from those focused on remediation of problems to those seeking to prevent problems. ${ }^{22}$ This article provides another take on this perspective, by paying close attention to emerging and consolidating practices and institutional forms for the governance and financing of such investments. In particular, it has argued that focusing exclusively on propositions about where to intervene - in the labour market or with child-centred spending - provides only a limited picture of adjustments in social policy thinking since the mid-1990s. Another quasi-concept is part of the assemblage. Social entrepreneurship is used to invoke promises of societal well-being such as social cohesion and of reducing poverty among children and 
families. Alongside the propositions about where to invest there has been an important change in the emphasis on who should provide the service (social enterprises and entrepreneurs), how it should be governed (as a non-profit enterprise, cooperative or such like) and how it should be financed (with a mix of public funds, philanthropy, and so on). All of these involve a reconfiguration of the welfare diamond, via a reliance on market-making and social enterprises.

As with social investment, enthusiasm for innovative governance has involved a mapping onto the broad cultural narrative of neoliberalism, via a discourse emphasising markets and entrepreneurship, at the same time as moving beyond neoliberalism to call for new services and new public spending. In this adjustment something has disappeared, of course. This is the consensus that state-designed policy instruments and public delivery of public services are the best kind of investment, whether the policy is one of increasing employment or investing in children. Instead, states, international organisations and the supranational EU are directing their spending to a myriad of social entrepreneurs and NGOs to provide the services, in one of the multiple legal forms that social enterprises might take.

This dimension of governance modification is important to consider in the context of identifying any new paradigm. If, after 1945, it was not imperative to include governance choices in social policy analysis because public provision was considered to be the natural choice, this is no longer the case. Neoliberals' enthusiasm for the new public management, for 'downsizing' and 'offloading', for markets and the voluntary sector, have all meant a weakening of the consensus around public provision. Choices must now be consciously made about governance arrangements for implementing the social investment perspective.

This article has argued that it is possible to identify a new paradigm, but it is built around not one but two quasi-concepts: social investment and social entrepreneurship. As with any paradigm there is a certain consensus on objectives, but a variety of instruments are identified to achieve them. Moreover, the article has demonstrated that a third characteristic of any paradigm is its reliance on cross-sectoral and cross-level linkages, which among other things involve promises of improved societal and individual outcomes. The assemblage of social investment and social entrepreneurship does just this, by promising to improve social cohesion, reduce poverty and augment the human capital of society as well as individuals via social investments delivered by social entrepreneurs.

\section{Notes}

1 Strasbourg Declaration, issued at the end of the conference Empowering Social Entrepreneurs for Innovation, Inclusive Growth and Jobs, January 2014. At: http://ec.europa.eu/internal_market/conferences/2014/o116-social-entrepreneurs/docs/ strasbourg-declaration_en.pdf, consulted 4 January 2015. 
2 For a similar call for assessing the potential connections between social investment and innovation see Ewert and Evers (2014). Rather than analysing the connections, however, they conclude their article by calling for a future analysis of social investment and social innovation (2014: 431).

3 This original formulation of the concept of paradigm avoids the trap into which many policy analysts have recently fallen, that is trying to distinguish 'ideas' from 'policy'. Daignault (2013) for example engages in an ultimately impossible effort to distinguish ideas (labelled 'a paradigm') from a policy. We prefer the original notion of paradigm as settings, instruments and objectives, all of which are composed of both ideas about policy and policy interventions.

4 For an overview of this approach to public policy and the concept of référentiel widely used in the French-language literature see Muller (2014). The similarity to Peter Hall's definition of paradigm accounts for the common practice of treating référentiel and paradigm as synonyms (Coleman, 1998; Morel et al., 2012: 11).

5 The notion of the welfare diamond extends Esping-Andersen's 'three pillars' which identify the state, market and family as the three sources of well-being. I believe that it is a mistake and misleading to try to subsume the welfare-generating community sector under the family corner of the triangle and to restrict the production of welfare to "markets (purchased welfare), families (the reciprocity of kin) and government (solidarity)" (Esping-Andersen et al., 2002: 4; 11). For the representation of four contributions to the welfare mix, see Evers et al. (1994) as well as Evers and Guillemard (2012).

6 This thesis can be summarised: 'The advanced Western nations' welfare states were built to cater to an economy dominated by industrial mass production. In the era of the 'Keynesian consensus' there was no perceived trade-off between social security and economic growth, between equality and efficiency' (Esping-Andersen, 1996: 3 ).

7 By the mid-199os the OECD, for example, warned of a 'malaise throughout society' and developed an autocritique. The opening paragraph of Societal Cohesion and the Globalising Economy begins: 'For over a decade, OECD countries have been committed to a cluster of economic policies aimed at encouraging macroeconomic stabilization, structural adjustment, and the globalisation of production and distribution. ... there is now pressure on many governments to take stock of the longer-term societal implications' such as 'increasing income polarisation, persistently high levels of unemployment, and widespread social exclusion...' (OECD, 1997: 3).

8 The move to embrace social investment, for example, varied across regime types (for example, Morel, Palier and Palme, 2012; Deeming and Smyth, 2015) as well as across regions (Jenson, 2010).

9 The EU focuses on education this way: 'Modernising social policies is a matter of common concern at EU level, as ineffective social policies in one country can have consequences for others, particularly within the Eurozone. Insufficient investment in social policies that strengthen human capital development, for instance in early childhood education and care, is manifested in lower educational levels and overall lower skill development in some Member States.' This is from the lead paragraph in section 2, 'What is needed' of the Social Investment Package (European Commission, 2013b: 8).

10 The dedication is: 'For today's children who will provide for our welfare when we are old. It is for you - and hence for ourselves - that we desire the best possible welfare state' (EspingAndersen et al. 2002: v). This analysis has been codified as the postulate that 'good pension policies - like good health policies - begin at birth' (Vandenbroucke et al., 2011: 6).

11 Of course scepticism exists about the policies' capacity to achieve fundamental goals of social equality, equity or even inclusion. Criticisms come from those concerned particularly 
about equality of outcomes, whether of class or gender (for example, Jenson, 2008; Mahon, 2010; Cantillon and Van Lancker, 2013).

12 This is the standard term used for a range of activities by social enterprises focused on integrating individuals into work. Among others see Evers et al. (2014), Nyssens (2006) or Nicholls and Murdock, 2012: 115.

13 For one recent discussion of some examples of market reconfiguration see Nicholls and Murdock (2012: especially chapters 3, 5, 6).

14 The 2014 Rome Strategy for the social economy provides this definition of the social economy: '... 'Social Economy' refers to a universe of organisations based on the primacy of people over capital. Their aim is providing goods, services or jobs to their members or to the community at large with a long-term perspective, with the participation of members-stakeholders in the governance of the organisation, and through the reinvestment of profits in their mission. This universe includes organisational forms like cooperatives, mutuals, foundations and associations, as well as newer forms like social enterprises, in the various meanings that this term takes on in different cultural and geographic contexts.' At: http://www.socialeconomyrome.it/files/Rome\%2ostrategy_EN.pdf. The UK has the most social economy organisations in Europe, with Germany a distant second. The other countries trail very far behind in numbers of such organisations (Social Europe, 2013: 47).

15 This was initially intended to be a broad initiative (http://europa.eu/rapid/pressrelease_IP-11-1238_en.htm?locale=en, consulted 4 January 2015). But a Google search (5 January 2015) on 'social business initiative' leads to a webpage titled 'social entrepreneurship'. Multinationals and even SMEs, targeted in 2011, are nowhere to be found.

16 http://ec.europa.eu/internal_market/social_business/index_en.htm (consulted 4 January 2015). This attention to social business with innovative potential is not to be confused with Innovation Union (http://ec.europa.eu/research/innovation-union/index_en.cfm, consulted 4 January 2015) which focuses on technological innovation and whose new 'innovation indicator' has nothing 'social' about it. See http://europa.eu/rapid/pressrelease_IP-13-831_en.htm, consulted 4 January 2015.

17 Given that social businesses, according to the EU's conceptualisation, may contribute to smart, sustainable or inclusive growth, 'their key aim is to effect social and economic transformation that contributes to the objectives of the Europe 2020 Strategy'. See http://ec.europa.eu/internal_market/publications/docs/sbi-brochure/sbi-brochureweb_en.pdf, consulted 5 January 2015.

18 See the conference proceedings at http://ec.europa.eu/internal_market/conferences/2014/ o116-social-entrepreneurs/workshops/index_en.htm, consulted 5 January 2015.

19 Similar innovations to incite the mobilisation of non-public providers were developed in the health and education domains (Blomqvist, 2004). The privatisation of schools provoked controversy when a major company decided to get out of the business in 2013, leaving thousands of students without a school. See http://www.theguardian.com/ education/2013/may/31/free-schools-education, consulted 5 January 2015.

20 The cooperative is the second most common form of organisation in the social economy (Social Europe, 2013: 46).

21 The pace of growth was affected by the on-going debates in Sweden over how to treat commercial childcare providers. The centre-right governments tended to want to allow them to receive public funds from both the central and municipal governments as any nonprofit alternative institution would. The Social Democrats wanted to reserve public funding for non-profits (Brennan et al., 2012: 382-83).

22 This emphasis on prevention was an early theme for the social investment perspective (Jenson and Saint-Martin, 2003: 92-95). 


\section{References}

Bernard, P. (1999), 'La cohésion sociale: critique dialectique d'un quasi-concept', Lien social et Politiques, \#41, 47-59.

Blomqvist, P. (2004), 'The Choice Revolution. Privatization of Swedish Welfare Services in the 1990s', Social Policy \& Administration, 38, 2, 139-55.

Bonoli, G. (2005), 'The politics of the new social policies: providing coverage against new social risks in mature welfare states', Policy \& Politics, 33, 3, 431-49.

Brennan, D., Cass, B., Himmelweit, S. and Szebehely, M. (2012), 'The marketisation of care: Rationales and consequences in Nordic and liberal care regimes', Journal of European Social Policy, 22, 4, 377-91.

Cantillon, B. and Van Lancker, W. (2013), 'Three Shortcomings of the Social Investment Perspective', Social Policy and Society, 12, 4, 553-64.

Capacity (2008), Social Enterprise: A childcare solution for London? Available at http://www.capacityltd.org.uk/docs/Social_Enterprise_Report.pdf.

Coleman, W. (1998), 'From protected development to market liberalism: paradigm change in agriculture', Journal of European Public Policy, 5, 4, 632-51.

Daignault, P.-M. (2013), 'Reassessing the concept of policy paradigm: Aligning ontology and methodology in policy studies', Journal of European Public Policy, 21, 3, 481-84.

Deeming, C. and Smyth, P. (2015), 'Social Investment after Neoliberalism. Policy Paradigms and Political Platforms', Journal of Social Policy, 44, 2, 297-318.

Dufour, P., Dobrowolsky, A., Jenson, J., Saint-Martin, D. and White, D. (2008), 'Emergence d'un référentiel global sous tension : l'investissement social au Canada', in O. Giraud and P. Warin (eds), Politiques publiques et démocratie. Paris: La Découverte, 179-98.

Esping-Andersen, G. (ed.) (1999), Social Foundations of Postindustrial Economies. NY: Oxford University Press.

Esping-Andersen, G., Gallie, D., Hemerijck, A. and Myles, J. (2002), Why we need a new welfare state. Oxford: Oxford University Press.

European Commission (2013a), Recommendation. Investing in Children. Breaking the cycle of disadvantage. COM (2013) 778 final.

European Commission (2013b), Towards Social Investment for Growth and Cohesion - including implementing the European Social Fund 2014-2020. COM (2013) 83 final.

European Commission (2013c), Social Innovation Research in the European Union. Approaches, Findings and Future Directions. Policy Review. Brussels: DG Research and Innovation. Available at http://ec.europa.eu/research/social-sciences/library_en.html.

Evans, P. and Sewell, Jr, W. (2013), 'Neoliberalism: Policy Regimes, International Regimes and Social Effects', in P.A. Hall and M. Lamont (eds), Social Resilience in the Neoliberal Era. NY: Cambridge University Press, 35-68.

Evers, A., Ewert, B. and Brandsen, T. (eds.) (2014), Social Innovations for Social Cohesion. Liege: EMES.

Evers, A. and Guillemard, A.-M. (eds.) (2012), Social Policy and Citizenship. Oxford: Oxford University Press.

Evers, A., Pilj, M. and Ungerson, C. (eds.) (1994), Payments for Care. A Comparative Overview. Aldershot: Avebury.

Ewert, B. and Evers, A. (2014), 'Blueprints for the Future of Welfare Provision? Shared Features of Service Innovations across Europe', Social Policy and Society, 13, 3, 423-32.

Hall, P.A. (1989), The Political Power of Economic Ideas. Keynesianism across Nations. Princeton, NJ: Princeton University Press.

Hall, P.A. (1993), 'Policy Paradigms, Social Learning, and the State: The Case of Economic Policymaking in Britain', Comparative Politics, 25, 3, 275-96.

Jenson, J. (1989), “'Different but not exceptional." Canada's permeable fordism', Canadian Review of Sociology and Anthropology, 26, 1, 70-94.

Jenson, J. (2008), 'Writing Women Out, Folding Gender In. The European Union "Modernises” Social Policy', Social Politics. International Studies in Gender, State and Society, 15, 2, 1-23. 
Jenson, J. (2010), 'Diffusing ideas for after neo-liberalism: The social investment perspective in Europe and Latin America', Global Social Policy, 10, 1, 59-84.

Jenson, J. (2012), 'A new politics for the social investment perspective: Objectives, instruments and areas of intervention in welfare regimes', in G. Bonoli and D. Natali (eds), The Politics of the New Welfare State. Oxford: Oxford University Press, 21-44.

Jenson, J. and Saint-Martin, D. (2003), 'New routes to social cohesion? Citizenship and the social investment state', Canadian Journal of Sociology, 28, 1, 77-99.

Jenson, J. and Levi, R. (2013), 'Narratives and Regimes of Social and Human Rights: The Jackpines of the Neoliberal Era', in P.A. Hall and M. Lamont (eds), Social Resilience in the Neoliberal Era. NY: Cambridge University Press, 69-98.

Kennett, P. and Lendvai, N. (2014), 'Policy paradigms, gender equality and translation: scales and disjuncture', Journal of International and Comparative Social Policy, 30, 1, 6-16.

Mahon, R. (2010), 'After-Neoliberalism? The OECD, the World Bank and the Child', Global Social Policy, 10, 2, 172-92.

Mahon, R. and McBride, S. (eds.) (2008), The OECD and Transnational Governance. Vancouver: UBC Press.

Milbourne, L. and Cushman, M. (2015), 'Complying, Transforming or Resisting in the New Austerity? Realigning Social Welfare and Independent Action among English Voluntary Organisations', Journal of Social Policy, 44, 3, 463-85.

Morel, N., Palier, B. and Palme, J. (eds.) (2012), Towards a social investment welfare state? Ideas, policies and challenges. Bristol, UK: Policy Press.

Moulaert, F., Martinelli, F., Swyngedouw, E. and González, S. (eds.) (2010), Can Neighbourhoods Save the City? Community Development and Social Innovation. Milton Park: Routledge.

Muller, P. (2014), 'Référentiel', in L. Boussaguet et al.. Dictionnaire des politiques publiques. Paris: Presses des Sciences Po, 555-62.

Nicholls, A. and Murdock, A. (eds.) (2012), Social Innovation. Blurring Boundaries to Reconfigure Markets. Basingstoke, Hampshire: Palgrave Macmillan.

Nyssens, M. (ed.). (2006), Social Enterprise at the Crossroads of Market, Public Policies and Civil Society. Milton Park: Routledge.

OECD (1997), Societal Cohesion and the Globalising Economy. Paris: OECD.

OECD (2005), Babies and Bosses. Reconciling Work and Family Life, vol. 4. Paris: OECD.

OECD (2010a), The OECD Innovation Strategy. Getting a Head Start on Tomorrow. Paris: OECD.

OECD (2010b), SMEs, Entrepreneurship and Innovation. OECD: Paris.

OECD (2014), OECD Family Database. OECD: Paris(www.oecd.org/social/family/database).

SEL [Social Enterprise London] (2002), Social Enterprise guide to Childcare. London: SEL.

Social Europe (2013), Social Economy and Social Entrepreneurship, Social Europe Guide \#4.

Vandenbroucke, F., Hemerijck, A. and Palier, B. (2011), The EU needs a social investment pact, Observatoire social européen Opinion Paper \#5. Brussels: OSE.

Van Kersbergen, K. and Hemerijck, A. (2012), 'Two Decades of Change in Europe: The Emergence of the Social Investment State', Journal of Social Policy, 41, 3, 475-92. 